\title{
Spatio-temporal patterns of Holocene environmental change in southern Sicily
}

\author{
Camilla Calò a,*, Paul D. Henne a, Brandon Curry ${ }^{\text {b }}$, Michel Magny ${ }^{\text {c }}$, Elisa Vescovi a ${ }^{\text {a }}$ Tommaso La Mantia ${ }^{\text {d }}$, \\ Salvatore Pasta ${ }^{\mathrm{e}}$, Boris Vannière ${ }^{\mathrm{c}}$, Willy Tinner ${ }^{\mathrm{a}}$ \\ a Oeschger Centre for Climate Change Research E Institute of Plant Sciences, University of Bern, Altenbergrain 21, CH-3013 Bern, Switzerland \\ b Illinois State Geological Survey, Institute of Natural Resource Sustainability, UIUC, 615 E. Peabody Dr., Champaign, IL 61820, USA \\ c Laboratoire de Chrono-Environnement, UMR 6249 du CNRS, UFR des Sciences et techniques, 16 route de Gray, F-25030 Besançon, France \\ d Dipartimento di Colture Arboree, Facoltà di Agraria, Viale delle Scienze 11, I-90128 Palermo, Italy \\ e Via V. F. 19 n_60/A, I-90126 Palermo, Italy
}

\section{A R T I C L E I N F O}

\section{Article history:}

Received 8 December 2011

Received in revised form 24 January 2012

Accepted 29 January 2012

Available online 10 February 2012

\section{Keywords}

Mediterranean

Sicily

Paleohydrology

Holocene

Climate change

Paleoecology

\begin{abstract}
A B S T R A C T
Few examples of natural forest remain near the Mediterranean coast. Therefore, it is difficult to study how coastal forests respond to climatic change or their resilience to human impact.

We developed new sedimentary record of Holocene vegetation and fire history at Lago Preola, a coastal lake in southwestern Sicily (Italy). In order to verify the existence of forest at large scale on the coast, we compare pollen from Lago Preola, a medium-sized lake (33 ha), to Gorgo Basso, a small lake (3 ha) located nearby with the aim of separating local from extra-local vegetation dynamics through time using pollen percentages and influx. We then compare Lago Preola pollen to the record from Biviere di Gela, a large lagoon (120 ha) situated $160 \mathrm{~km}$ to the east in southern Sicily, to examine differences in vegetation dynamics between the two coastal areas during the Holocene. Lake-level reconstructions and ostracode analyses from Lago Preola provide vegetation-independent evidence of climate change, and help to disentangle human and climatic impacts on vegetation. Pollen data indicate Pistacia-dominated shrublands replaced open grasslands in the region surrounding Lago Preola by $9500 \mathrm{cal} \mathrm{yr} \mathrm{BP.} \mathrm{This} \mathrm{change} \mathrm{coincided} \mathrm{with} \mathrm{rising} \mathrm{lake} \mathrm{levels} \mathrm{and} \mathrm{the}$ development of an ostracode fauna typical of fresh waters. Evergreen forest dominated by Quercus ilex and Olea europaea started to expand by $7000 \mathrm{cal} \mathrm{BP}$ and consolidated at $6500 \mathrm{cal}$ yr BP, when lake levels were near their Holocene high. Similarities between pollen from Lago Preola and Gorgo Basso demonstrate that forest was the dominant vegetation type in coastal Sicily during the middle Holocene at both regional and local scales, and even developed in the drier climatic setting around Biviere di Gela. Lake levels fell at Lago Preola after $7000 \mathrm{cal} \mathrm{yr} \mathrm{BP,} \mathrm{with} \mathrm{a} \mathrm{strong} \mathrm{decline} \mathrm{accompanied} \mathrm{by} \mathrm{increasing} \mathrm{salinity} \mathrm{after} 4500 \mathrm{cal}$ yr BP. However, no transition in vegetation matched these inferred hydrological changes. Instead, forests persisted in the surrounding region until $2200 \mathrm{cal} \mathrm{BP}$ when human disturbance intensified. We propose that different climatic factors control lake levels and vegetation in coastal Mediterranean ecosystems. Whereas lake levels are most sensitive to the abundance of winter precipitation, coastal forests depend on spring precipitation and are limited by the length of summer drought. Moisture availability remained suitable for evergreen forests in coastal Sicily during the late Holocene, and humans, not a drier climate drove the regional forest decline.
\end{abstract}

(C) 2012 Elsevier B.V. All rights reserved.

\section{Introduction}

Ecosystems in the Mediterranean basin have been shaped by millennia of intense landuse. Consequently, it is difficult to distinguish the impacts of human disturbance and climatic change on past vegetation dynamics, or even what vegetation types would be dominant on a regional scale in the absence of frequent disturbance (Allen, 2003; Vogiatzakis et al., 2006). Paleoecological reconstructions provide a means to assess the natural dynamics of Mediterranean

\footnotetext{
* Corresponding author. Tel.: +413163135 97; fax: +41316314942. E-mail address: camilla.calo@ips.unibe.ch (C. Calò).
}

ecosystems, and to investigate how these systems respond to climatic change and human disturbance. For example, pollen-inferred vegetation reconstructions indicate that closed forests grew at low altitude near the Mediterranean coast during the mid-Holocene in areas that are currently dominated by maquis, (i.e., evergreen shrublands; Carriòn, 2002; Colombaroli et al., 2007; Colombaroli et al., 2009).These studies are consistent with the only two records from coastal Sicily, Gorgo Basso and Biviere di Gela (Noti et al., 2009; Tinner et al., 2009;). At Gorgo Basso, closed evergreen forests replaced maquis around $7000 \mathrm{cal}$ yr BP, probably due to increasing regional moisture. The presence of a forest around Gorgo Basso was inferred from high percentage and influx values of pollen from evergreen trees (i.e., Quercus ilex, Olea europaea, $\mathrm{AP}>60 \%$ at 
5000 cal yr BP) when compared with the very low abundances for the last 2100 years (Tinner et al., 2009). Tree abundance was also high at Biviere di Gela between 7000 and 2500 cal yr BP (AP>60\% at ca 5500 cal yr BP), although the surrounding landscape was probably more open.

The disappearance of forests at Gorgo Basso and decline in trees at Biviere di Gela after 2500 cal yr BP was interpreted as a consequence of increasing human disturbance and fire activity, suggesting that forests could persist under the current climate (Noti et al., 2009; Tinner et al., 2009;). However, the decline of forests during the middle and late Holocene is observed throughout the Mediterranean region, and some authors attribute this change to a regional decline in moisture availability (Sadori and Narcisi, 2001; Roberts et al., 2011). Furthermore, it is unclear whether the closed forest near Gorgo Basso during the mid Holocene resulted from a favorable local microclimate due to moist conditions near the lake, or if the regional landscape was more open like at Biviere di Gela. Additional paleoecological reconstructions are needed to resolve what vegetation types were dominant on a regional scale near the Mediterranean coast during the Holocene, and to evaluate how climatic change and human impacts affect these ecosystems.

In this paper, we present a pollen-inferred vegetation reconstruction from Lago Preola in southwestern Sicily. This new lake-sediment pollen record allows us to examine human and climatic impacts on vegetation dynamics during the Holocene in Sicily on three spatial scales. We first separate local and landscape-scale vegetation dynamics by comparing the pollen of Lago Preola, a medium-sized lake (ca. 33 ha surface area) with pollen from Gorgo Basso (Tinner et al., 2009), a small lake of ca. 3 ha only $1 \mathrm{~km}$ away. The pollen source area of a lake varies with lake size. Therefore, adjacent lakes with different sizes may be used to separate local and regional vegetation dynamics (Jackson, 1990; Sugita, 1994; Conedera et al., 2006; Hofstetter et al., 2006;). Because of the proximity of Lago Preola and Gorgo Basso, differences in pollen assemblages should relate to local vs. regional-scale differences in vegetation, not climate or disturbance history. Although the shape of a lake also affects pollen accumulation (Sugita, 1993), we assume that the 10-fold difference in surface area between Gorgo Basso and Lago Preola is more important than differences in the shapes of these lakes. We also evaluate regional variation in vegetation dynamics by comparing pollen from Lago Preola to Biviere di Gela, a large lagoon (120 ha) situated $160 \mathrm{~km}$ to the east on the southern Sicilian coast (Noti et al., 2009). Our comparison between these sites allows us to extend the implications of our findings to a broader spatial scale. We also compare our new Lago Preola pollen record to proxies for hydrological change from the same sediments. A lake-level reconstruction (Magny et al., 2011) and new ostracode analysis, presented here, provide vegetation-independent evidence of changes in moisture availability. Our integrative, multiproxy approach allows us to identify the past distribution of coastal forests (e.g., restricted to favorable local habitats vs. regional distribution), and evaluate the importance of human and climatic impacts on vegetation change at multiple scales.

\section{Material and methods}

\subsection{Study area}

Lago Preola is a medium-sized lake of ca. 33 ha, located near the southwestern coast of Sicily $\left(37^{\circ} 37 \mathrm{~N}, 12^{\circ} 38 \mathrm{E}, 6 \mathrm{~m}\right.$ a.s.l.; Fig. 1$)$. The lake has no surface inlet or outlet, and is part of a chain of karstic depressions that are separated from the Mediterranean Sea $(1.5 \mathrm{~km}$ away) by a calcareous ridge ca $30-40 \mathrm{~m}$ high (Fig. 1). The area is an important refuge for various endangered animals, and is part of a WWF protected area, "Riserva Naturale Integrale Lago Preola e Gorghi Tondi." Lago Preola has a typical Mediterranean climate, with hot, dry summers and mild, moist winters. Mean annual air temperature at the nearby weather station in Mazara del Vallo $(5 \mathrm{~km}$ from Lago Preola) is $18.2{ }^{\circ} \mathrm{C}$, with $26.3{ }^{\circ} \mathrm{C}$ in August, and $11.4{ }^{\circ} \mathrm{C}$ in January (source: Osservatorio delle Acque, Regione Siciliana; Bonaccorso et al., 2003). Precipitation is most abundant during the fall and winter $(177 \mathrm{~mm})$, and little precipitation falls during the summer months $(16 \mathrm{~mm}$; Fig. 2). Two other lakes are considered in the present study. The nearby lake, Gorgo Basso ( $6 \mathrm{~m}$ a.s.l.), is much smaller, with a surface area of ca 3 ha, and is part of the same chain of karstic depressions as Lago Preola (Tinner et al., 2009). Biviere di Gela is a large coastal lagoon (120 ha, $7 \mathrm{~m}$ a.s.l.) located $160 \mathrm{~km}$ to the southeast (Noti et al., 2009).

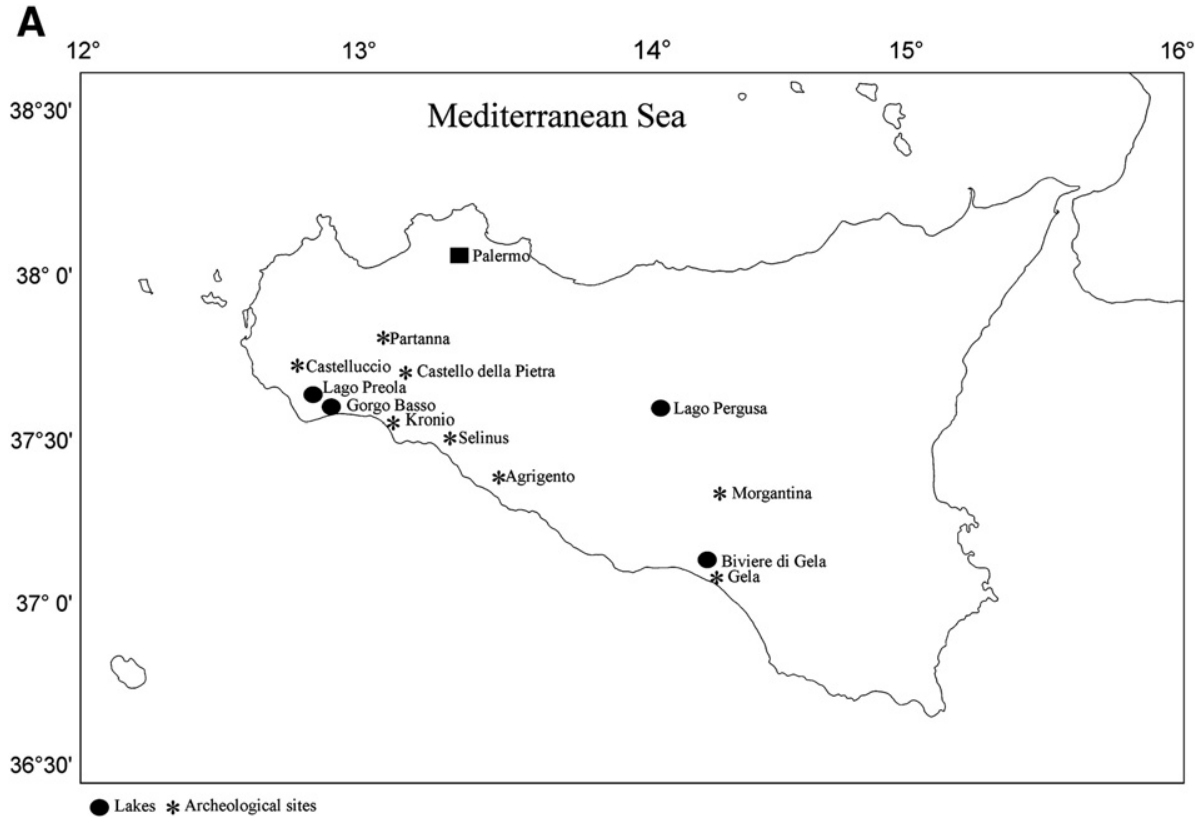

Fig. 1. A. Map showing Sicily with the location of study sites and archeological sites mentioned in the text. B. Local vegetation around Lago Preola and Gorgo Basso. Modified from Brullo and Ronsisvalle, 1975 and from Tinner et al., 2009. 


\section{B}

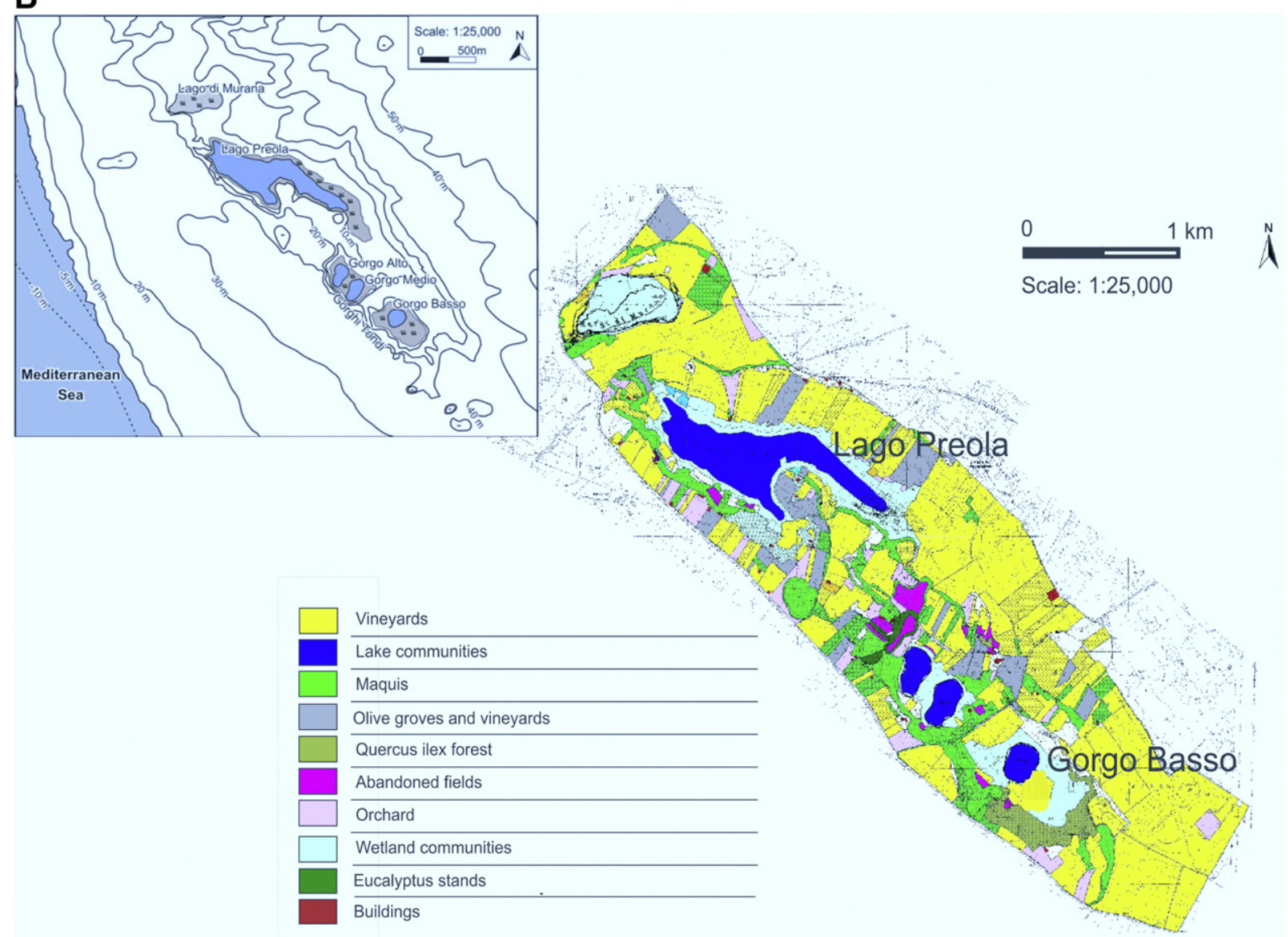

Fig. 1 (continued).

Most of the landscape surrounding Lago Preola is managed for agriculture, with vineyards, olive groves, and orchards (Fig. 1B). However, maquis and a fragment of evergreen forest vegetation are also present nearby (Brullo and Ronsisvalle, 1975). These communities belong to the Quercetea ilicis class typical of calcareous substrates in the thermo-Mediterranean bioclimate, and the most representative species are Quercus ilex, Quercus coccifera, Pistacia lentiscus, Rhamnus alaternus, Rhamnus lycioides subsp. oleoides and Chamaerops humilis. Small grassland communities dominated by Ampelodesmos mauritanicus, Hyparrhenia hirta, and Carlina sicula are also present. Several rare species occur in the aquatic and hygrophilous communities of the reserve, such as Cladium mariscus, Juncellus laevigatus, Damasonium bourgaei, Galium elongatum and Hypericum tetrapterum (Ottonello et al., 2003). Halophyte species, including Arundo donax L. and Arthrocnemum macrostachyum (Moric.) have been observed along the shores of Lago Preola since 1975, suggesting a recent increase in salinity.

\subsection{Coring and dating}

Parallel cores LPB and LPC, were taken in June 2008 from the center of Lago Preola where the water depth was $2 \mathrm{~m}$. We visually
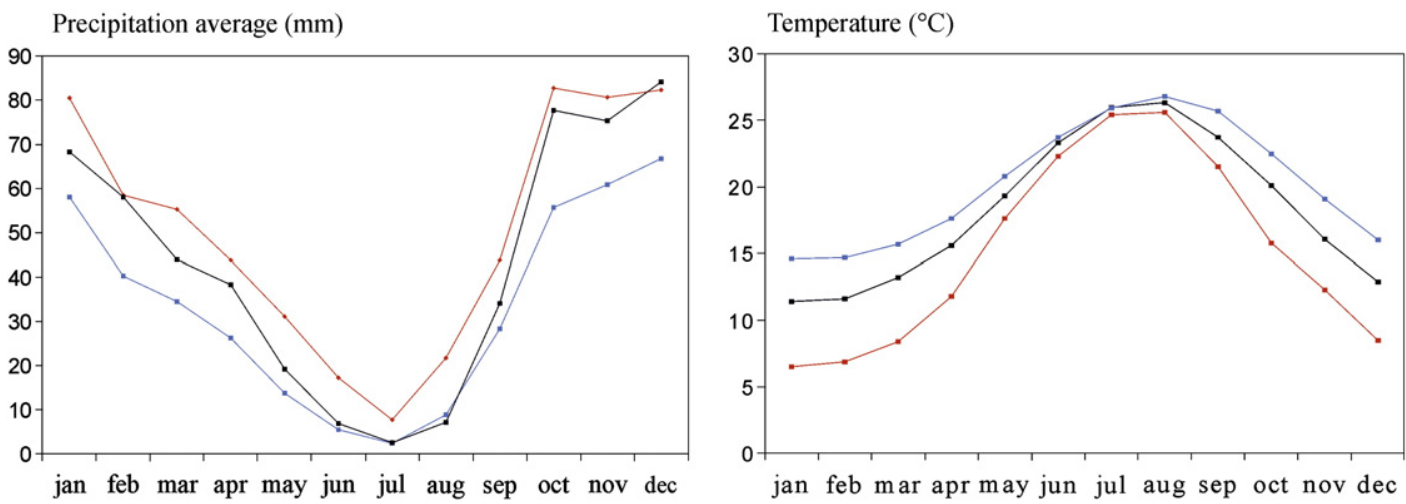

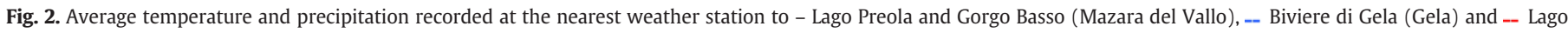
Pergusa (Granci) during the period 1925-2003.

Osservatorio delle Acque, della Regione Siciliana. 
Table 1

AMS radiocarbon dates obtained from cores LPA and LPBC.

\begin{tabular}{|c|c|c|c|c|c|}
\hline Core & $\begin{array}{l}\text { Depth } \\
(\mathrm{cm})\end{array}$ & Radiocarbon date & Calibrated age at 2 sigma range & Material & Lab. reference \\
\hline Core LPA & $44-45$ & $1600 \pm 30 \mathrm{BP}$ & $1546-1410$ & Peat & Poz-27885 \\
\hline Core LPA & $157-158$ & $4120 \pm 35 \mathrm{BP}$ & $4821-4527$ & Peat & Poz-30094 \\
\hline Core LPA & $234-235$ & $5140 \pm 40 \mathrm{BP}$ & $5990-5751$ & Carex seeds and wood fragments & Poz-27886 \\
\hline Core LPA & $310-311$ & $5340 \pm 40 \mathrm{BP}$ & $6271-5998$ & Peat & Poz-30095 \\
\hline Core LPA & $461-462$ & $6220 \pm 40 \mathrm{BP}$ & $7252-7007$ & Peat & Poz-30096 \\
\hline Core LPA & $602-603$ & $7940 \pm 50 \mathrm{BP}$ & $8990-8634$ & Peat & Poz-32423 \\
\hline Core LPA & $673-674$ & $8930 \pm 50 \mathrm{BP}$ & $10,227-9906$ & Peat & Poz-30097 \\
\hline Core LPA & $808-809$ & $9360 \pm 60 \mathrm{BP}$ & $11,063-10,265$ & Peat & Poz-33875 \\
\hline Core LPBC & $131-132$ & $2280 \pm 40 \mathrm{BP}$ & $2353-2158$ & Wood fragments & Poz-33867 \\
\hline Core LPBC & $401-402$ & $4400 \pm 40 \mathrm{BP}$ & $5267-4858$ & Peat & Poz-33870 \\
\hline Core LPBC & $493-494$ & $5160 \pm 40 \mathrm{BP}$ & $6095-5748$ & Peat & Poz-33871 \\
\hline Core LPBC & $735-736$ & $7610 \pm 40 \mathrm{BP}$ & $8538-8345$ & Peat & Poz-33874 \\
\hline
\end{tabular}

correlated the cores to produce a continuous sedimentary sequence (i.e. core LPBC; Magny et al., 2011). For consistency between our new pollen record, and the lake-level reconstruction from Lago Preola, we use the age-depth model that is described in detail by Magny et al. (2011). This chronology is based on 4 calibrated AMS radiocarbon dates of terrestrial plant material and bulk sediments from LPBC (Table 1; Stuiver et al., 1998; Reimer et al., 2004), 3 dates derived from sedimentary correlation with a core taken in the littoral zone in $<10 \mathrm{~cm}$ of water (core LPA), and 9 dates from correlation with the well-dated pollen stratigraphy of Gorgo Basso (Fig. 3; Tinner et al., 2009; Magny et al., 2011). Pollen correlations with Gorgo Basso were determined from the sum of trees, shrubs and herbs and not individual taxa. Although this approach introduces the possibility of chronological circularity, in this paper we do not focus on the timing of changes but on the comparison of vegetation composition from the two sites.

\subsection{Pollen and microscopic charcoal}

Subsamples of $1 \mathrm{~cm}^{3}$ were taken every $16 \mathrm{~cm}$ from core LPBC for pollen and microscopic charcoal analysis from the sediments above $844 \mathrm{~cm}$ (average time resolution $120 \mathrm{yr} /$ sample $\pm 20 \mathrm{SD}$ ). We sampled every $4 \mathrm{~cm}$ between 928 and $844 \mathrm{~cm}$ where our age-depth model indicates that sedimentation was slower, reaching a total of 65 samples.
Pollen preparation followed standard procedures for glycerin samples (Moore et al., 1991). Lycopodium tablets were added to estimate pollen concentrations (grains $\mathrm{cm}^{-3}$ ) and influx (grains $\mathrm{cm}^{-2} \mathrm{yr}^{-1}$; Stockmarr, 1971). Pollen and spore identification followed keys (e.g. Punt, 1976; Moore et al., 1991; Beug, 2004), pollen atlases (e.g. Reille, 1992), and the reference collection of the Institute of Plant Sciences of the University of Bern. The minimum number of pollen grains counted per slide was 400 , excluding pollen of water plants and spores. The pollen diagram was subdivided into local pollen assemblage zones (LPAZ) using the zonation method of optimal partitioning (Birks and Gordon, 1985). We determined the number of statistically significant zones with the program BSTICK (Bennett, 1996). We counted charcoal particles longer than $10 \mu \mathrm{m}$ on each pollen slide and calculated charcoal concentration (particles $\mathrm{cm}^{-3}$ ) and influx (particles $\mathrm{cm}^{-2} \mathrm{yr}^{-1}$; Stockmarr, 1971; Tinner and Hu, 2003; Finsinger and Tinner, 2005).

\subsection{Statistical comparison of complementary pollen records}

We evaluated differences in regional and local vegetation dynamics near Lago Preola, by comparing pollen percentages and pollen accumulation rates (PAR, or influx) of select pollen types from Lago Preola and Gorgo Basso. We also compared the Lago Preola record to Biviere di Gela to determine whether the vegetation dynamics recorded at Lago Preola were consistent with vegetation from the



Fig. 3. Age-depth model of core LPBC showing AMS ${ }^{14} \mathrm{C}$ dates and inferred ages. Redrawn from Magny et al., 2011. 


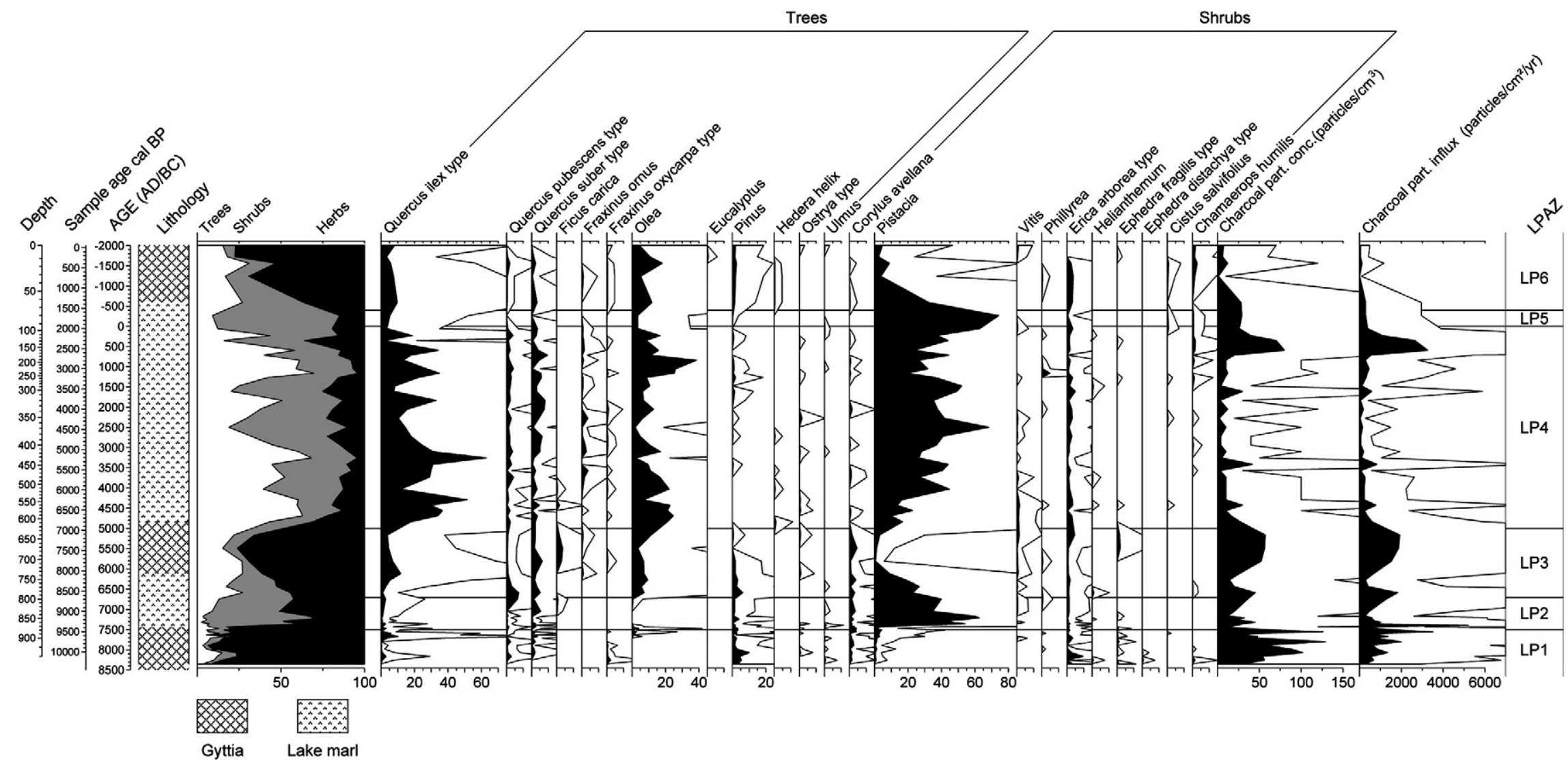

Fig. 4. Selected arboreal pollen percentages and charcoal concentration of core LPBC from Lago Preola. Empty curves show 10 $\times$ exaggerations. LPAZ $=$ local pollen assemblage zones. 
broader region. We summarized the combined Lago Preola and Gorgo Basso pollen percentage data using detrended correspondence analysis (DCA) with PAST 2.07 (Hammer et al., 2001). The gradient length of the first DCA axis was $<2$, therefore the unimodal response model was preferred to principal component analyses (PCA and RDA). DCA was applied only to species that occur in both sites (30 pollen types: ter Braak and Prentice, 1988).

\subsection{Proxies for hydrological change}

The LPBC core was used for high temporal-resolution lake-level reconstruction, based on a specific sedimentological approach in which macroscopic components were identified and counted in two fractions ( $>0.5 \mathrm{~mm}$, and $0.2 / 0.5 \mathrm{~mm}$; Magny et al., 2011). Contiguous subsampling (generally 2 to $3 \mathrm{~cm}$-thick samples) enabled the recognition of short-lived palaeohydrological events. In order to establish a lake-level curve, DCA was applied to a percentage matrix of the sedimentological markers.

To extract ostracodes, moist sediment subsamples (4-12 g) were pretreated with $1 \mathrm{~g}$ of $\mathrm{NaHCO}_{3}$ and boiling tap water, cooled, and wet sieved through a Tyler sieve with $0.15 \mathrm{~mm}$ openings. A total of 62 samples were obtained at $16 \mathrm{~cm}$ intervals. Ostracode valves were picked from the dried residue, and identified under a binocular microscope. Species identification followed Martens (1984) and Meisch (2000). We standardized the valve concentration of each sample to a wet weight of $5 \mathrm{~g}$.

\section{Results and interpretation}

\subsection{Lithology}

The sediments of core LPBC consist of gyttja from the core

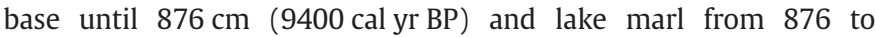
$736 \mathrm{~cm}$ (9400-8200 cal yr BP). A gyttja layer $(736-616 \mathrm{~cm}, 6700-$ 8200 cal yr BP) precedes a new lake marl formation $(616-60 \mathrm{~cm}$, $6700-1400$ cal yr BP). The sequence ends with a gyttja layer (60$0 \mathrm{~cm}, 1400-58 \mathrm{cal}$ yr BP). For a detailed lithological description see Magny et al. (2011).

\subsection{Pollen and vegetation history}

The oldest sediments from Lago Preola record the presence of open herb-dominated communities in the region. Between 10,300 and 9600 cal yr BP (Fig. 5 zone LP1) herbaceous pollen types including Poaceae, Cichorioideae, Apiaceae and Chenopodiaceae are abundant. Tree pollen, including Olea, Quercus ilex type Quercus pubescens type, and Quercus suber type constitute $<10 \%$ of the pollen sum, and the pollen influx of these types is very low (Figs. 4, 6). Despite percentages reaching $10 \%$, low Pinus influx $(<200$ pollen grains $\mathrm{cm}^{2} \mathrm{yr}^{-1}$ ) suggests long-distance transport as a possible source. Alternatively, it is possible that Pinus grew near Lago Preola during the early Holocene, although natural coastal Pinus populations are not known from Sicily at present. Shrub pollen percentages and influx are also low in zone LP1. However, Ephedra fragilis type, and Erica arborea type are present throughout, and Pistacia increases. The wetland and aquatic component is mainly formed by Sparganium type (60\%), but Cyperaceae and Cladium are also abundant.

A major increase in Pistacia pollen percentages (60\% of the pollen sum) and influx suggests that after 9600 cal yr BP shrublands developed near Lago Preola (zone LP2, Figs. 4, 6). Other shrubs, such as Vitis and Phillyrea, also increase in comparison with LP1, and Erica arborea type and Corylus maintain a low abundance. Phillyrea angustifolia (shrub) and Phillyrea latifolia (shrub or small tree) are both present in Sicily (Pignatti, 2005), though P. angustifolia is more abundant on the coast (Giardina et al., 2007). We thus assume that most pollen of Phillyrea is of $P$. angustifolia. Herbs generally decrease (e.g.
Apiaceae, Artemisia, Cichorioideae, and Chenopodiaceae) and tree pollen remains rare, with the highest abundances from Quercus pubescens type, Quercus suber type, and Pinus. Thus, the vegetation was probably comparable to extant evergreen Pistacia maquis. A decline in aquatic pollen types (e.g. Cyperaceae, Cladium, Thalictrum, Sparganium type) may indicate the area occupied by wetlands declined. At 9400 cal BP Pistacia pollen starts to decline.

Pistacia shrublands declined between 8500 and 7000 cal yr BP (Fig. 4 zone LP3). Tree pollen increases during this interval, when Quercus ilex type first expands, and the consistent presence of Olea is first recorded. However low tree-pollen influx (Fig. 6), and continued abundance of Poaceae is consistent with an open landscape with few trees. Other herbs including Aster type, Brassicaceae, Cichorioideae, and Caryophyllaceae also expand at this time. In addition, the zone is marked by the presence of typical anthropogenic indicators such as Ficus carica, Cerealia type, Rumex and Plantago lanceolata type.

An increase in Quercus ilex type and Olea pollen percentages characterizes zone LP4 (7000-2000 cal yr BP). These taxa expand after $7500 \mathrm{cal}$ yr BP, reaching almost $60 \%$ of the pollen sum, suggesting a trend in afforestation. Likewise, the pollen influx of $Q$. ilex type and Olea is highest during this period, consistent with the existence of forests or woodlands in the surrounding landscape. However, fluctuations in tree-pollen percentages are prominent in this zone, and Pistacia percentages and influx also increase (Fig. 4). Comparison with the percentages and influx values of the surface sediments at Gorgo Basso support our interpretation of evergreen forests near Lago Preola during the mid Holocene. Gorgo Basso is bordered on the southern shore is by a relict stand of $Q$. ilex forest. Despite the presence of this forest, $Q$. ilex-t contributes $<5 \%$ of the pollen sum and 500 pollen grains $\mathrm{cm}^{-2} \mathrm{yr}^{-1}$ in surface sediments from Gorgo Basso In contrast, even at the larger Lago Preola, in zone LP4, Q. ilex contributes between 10 and $50 \%$ of the pollen sum, and has an average influx $>3000$ grains $\mathrm{cm}^{-2} \mathrm{yr}^{-1}$. The low abundance of herbaceous pollen, notably Poaceae (Fig. 5), during LP4 further supports our interpretation of mid-Holocene forest. The herbaceous component stays very low for the entire period, with sparse presence of anthropogenic indicators such as Cerealia type, Rumex and Urtica dioica type. After $2700 \mathrm{cal} \mathrm{BP}$, the arboreal component decreases.

Zone LP5 (2000-1500 cal yr BP) is a short zone typified by abundant Pistacia ( $80 \%$ of the pollen sum) and low tree pollen (e.g. Quercus ilex type, Olea, and Fraxinus ornus), which probably indicates that Pistacia shrublands replaced forests near Lago Preola. However, the low abundance of herbaceous types in zone LP5 (in comparison to zones LP2 and LP3) suggests that Pistacia probably maintained a relatively closed canopy. Although the total abundance of herbaceous pollen remains low, pollen types indicative of disturbance expand, including Artemisia, Cerealia type, Chenopodiaceae, Mercurialis annua, Plantago lanceolata type, and Rumex (Fig. 5, LP5). Cistus salvifolius, and Chamaerops humilis, species favored by frequent fires, also expand (Fig. 4, LP5; Sanchez-Blanco et al., 2002; Pellizzaro et al., 2004).

Arboreal vegetation collapsed and the landscape near Lago Preola opened after $1500 \mathrm{cal} \mathrm{yr} \mathrm{BP} \mathrm{(Figs.} \mathrm{4,} \mathrm{5;} \mathrm{Zone} \mathrm{LP6).} \mathrm{Percentages} \mathrm{and} \mathrm{in-}$ flux of Quercus ilex type, Olea remain low, and Pistacia declines. Expansion by herbaceous taxa continued, including those favored by human disturbance (e.g. Cerealia type). Abundant Chenopodiaceae and Rumex probably indicate agricultural weeds. The major increase in Urtica dioica, may also relate to human activities, since it is favored by (anthropogenic) nitrogen enrichment (Ellenberg, 1996). Increases by Pinus and Eucalyptus pollen are consistent with plantations established during the last century.

\subsection{Microscopic charcoal and fire history}

Microscopic charcoal concentration and influx have similar trends. Since charcoal influx can be compared directly across different profiles and is considered a proxy for regional fire activity (Tinner et 


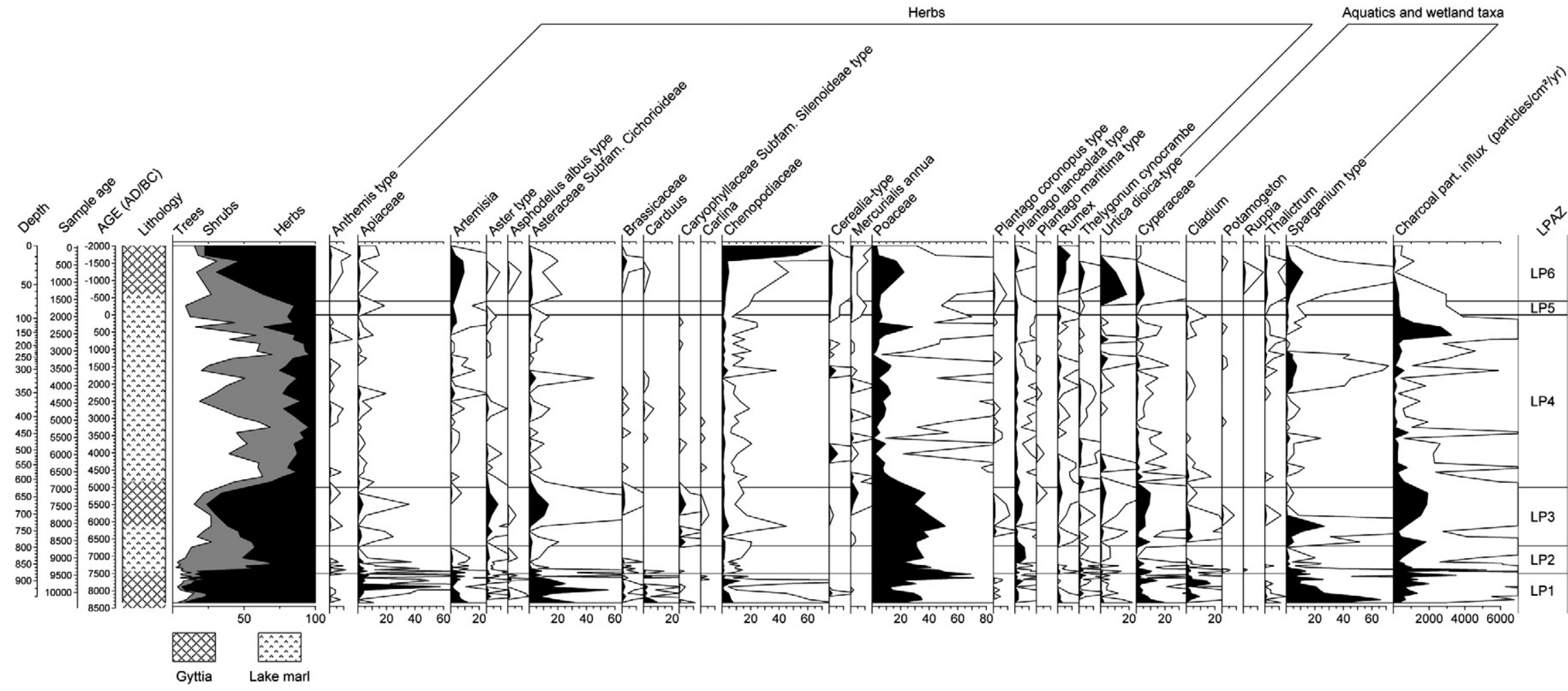

Fig. 5. Selected non arboreal pollen percentages and charcoal influx of core LPBC from Lago Preola. Empty curves show $10 \times$ exaggerations. LPAZ = local pollen assemblage zones. 
A) Lago Preola

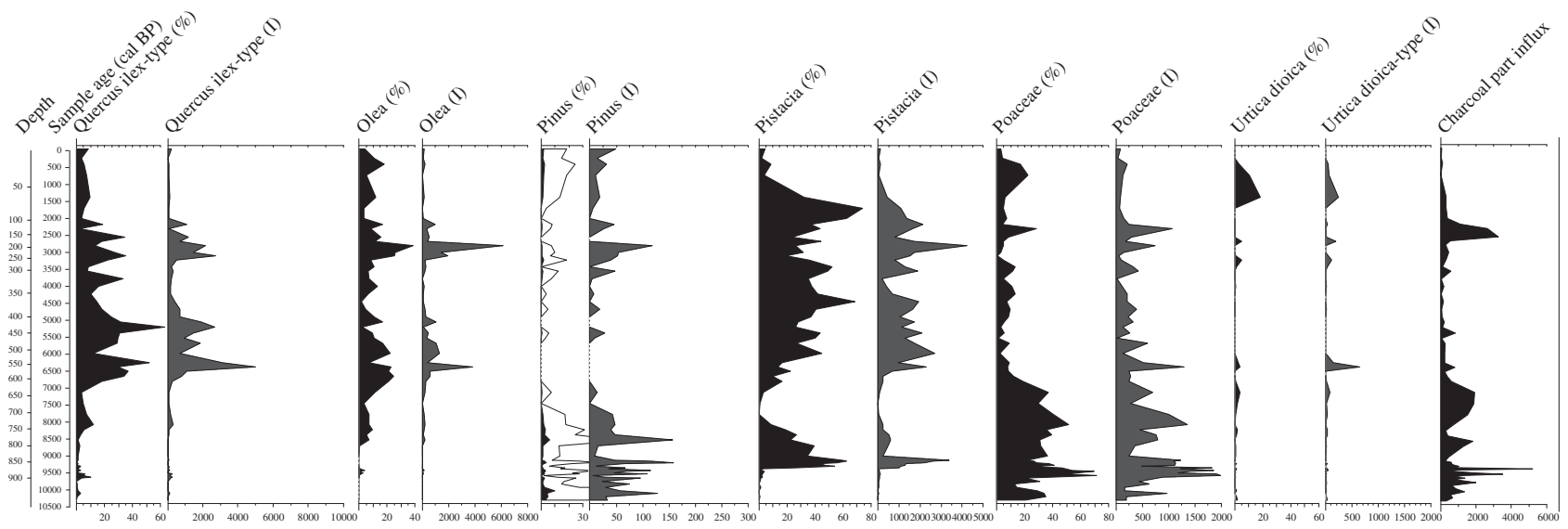

B) Gorgo Basso



C) Biviere di Gela



Fig. 6. Comparison between pollen percentages and influx of selected pollen taxa of Lago Preola, Gorgo Basso and Biviere di Gela. Empty curves show $10 \times$ exaggerations.

al., 1998), we refer only to the influx curve. Regional fire activity was high near Lago Preola before $6900 \mathrm{cal}$ yr BP. For example, the highest charcoal influx occurs in zone LP1 ca. 9600 cal yr BP (5213 particles c$\mathrm{m}^{-2} \mathrm{yr}^{-1}$; Fig. 4), when herbaceous communities dominated the surrounding landscape. Charcoal peaks also occur in zone LP3 (i.e. 4703 particles $\mathrm{cm}^{-2} \mathrm{yr}^{-1}$ at 8200 cal BP; 5800 particles $\mathrm{cm}^{-2} \mathrm{yr}^{-1}$ at $7800 \mathrm{cal} \mathrm{BP}$ ) when the landscape was relatively open. Fire activity was generally low during the interval when forests occurred at Lago Preola (i.e. Zone LP4; 7000-2000 cal yr BP). However, a peak in charcoal influx suggests high regional fire activity at 2540 cal yr BP (3269 particles $\mathrm{cm}^{-2}$ year $^{-1}$ ) when woodlands (tree pollen) declined. Charcoal influx generally declines in the upper zones LP5 and LP6, suggesting decreasing regional fire activity.

\subsection{Comparison of Lago Preola with Gorgo Basso and Biviere di Gela}

The first DCA axis closely follows the pollen abundance of trees that form evergreen forests, especially Quercus ilex type, Quercus 


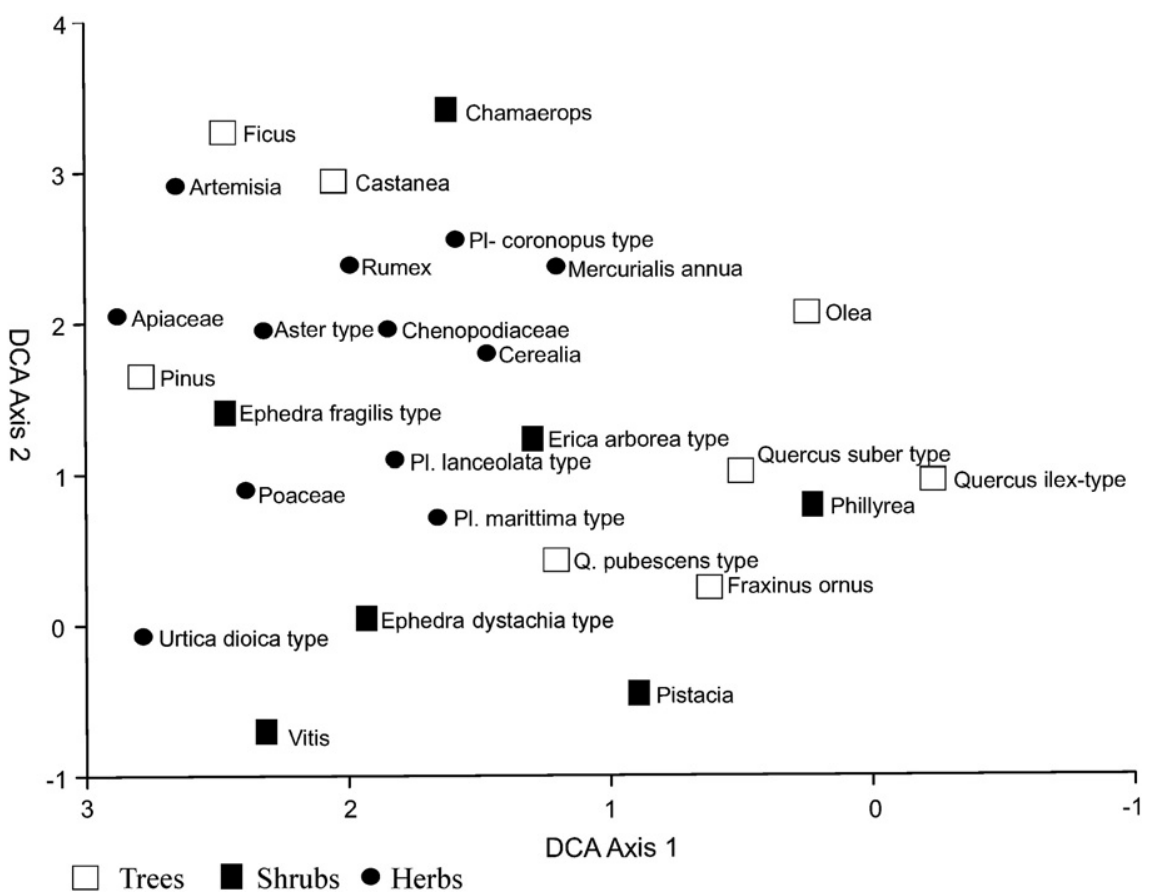

Fig. 7. Scatter plot of DCA species scores of pollen percentages from Lago Preola and Gorgo Basso.

suber type, and Olea. Thus temporal variations in DCA axis 1 follow transitions from forested to open landscapes (Figs. 7, 8). The curves from Lago Preola and Gorgo Basso show similar trends, with an open landscape during the early Holocene, a transition to forest after $7000 \mathrm{cal} \mathrm{yr} \mathrm{BP,} \mathrm{and} \mathrm{a} \mathrm{return} \mathrm{to} \mathrm{open} \mathrm{conditions} \mathrm{after}$ 2200 cal yr BP. Axis 1 scores are generally higher at Lago Preola than Gorgo Basso during the open landscape phases (Fig. 8). Scores on the second DCA axis follow the variability of Pistacia, and again the general temporal trends are very similar. However, axis 2 values are consistently higher at Lago Preola after $6000 \mathrm{cal} \mathrm{yr} \mathrm{BP.}$

Variations in percentages and influx are similar at Lago Preola, Gorgo Basso, and Biviere di Gela (Fig. 6). Rising percentages and influx of Quercus ilex type and Olea after 7000 cal BP are consistent with forest or woodland expansion at all three sites, although the increase in trees at Biviere di Gela occurred later (after 5500 cal yr BP). Poaceae tends to have higher influx and percentages at Biviere di Gela than Lago Preola and Gorgo Basso, throughout the sequence. The highest Pinus pollen influx occurs at Biviere di Gela ( 750 pollen grains $\mathrm{cm}^{-2} \mathrm{yr}^{-1}$ ) after $7500 \mathrm{cal} \mathrm{yr} \mathrm{BP.} \mathrm{However} \mathrm{during}$ the early Holocene $(10,500-8500$ cal yr BP), Pinus influx is only slightly lower at Lago Preola and Gorgo Basso. Urtica dioica type generally shows very low percentages and influx at Lago Preola and Biviere di Gela, but is relatively abundant at Gorgo Basso before 7000 cal yr BP.

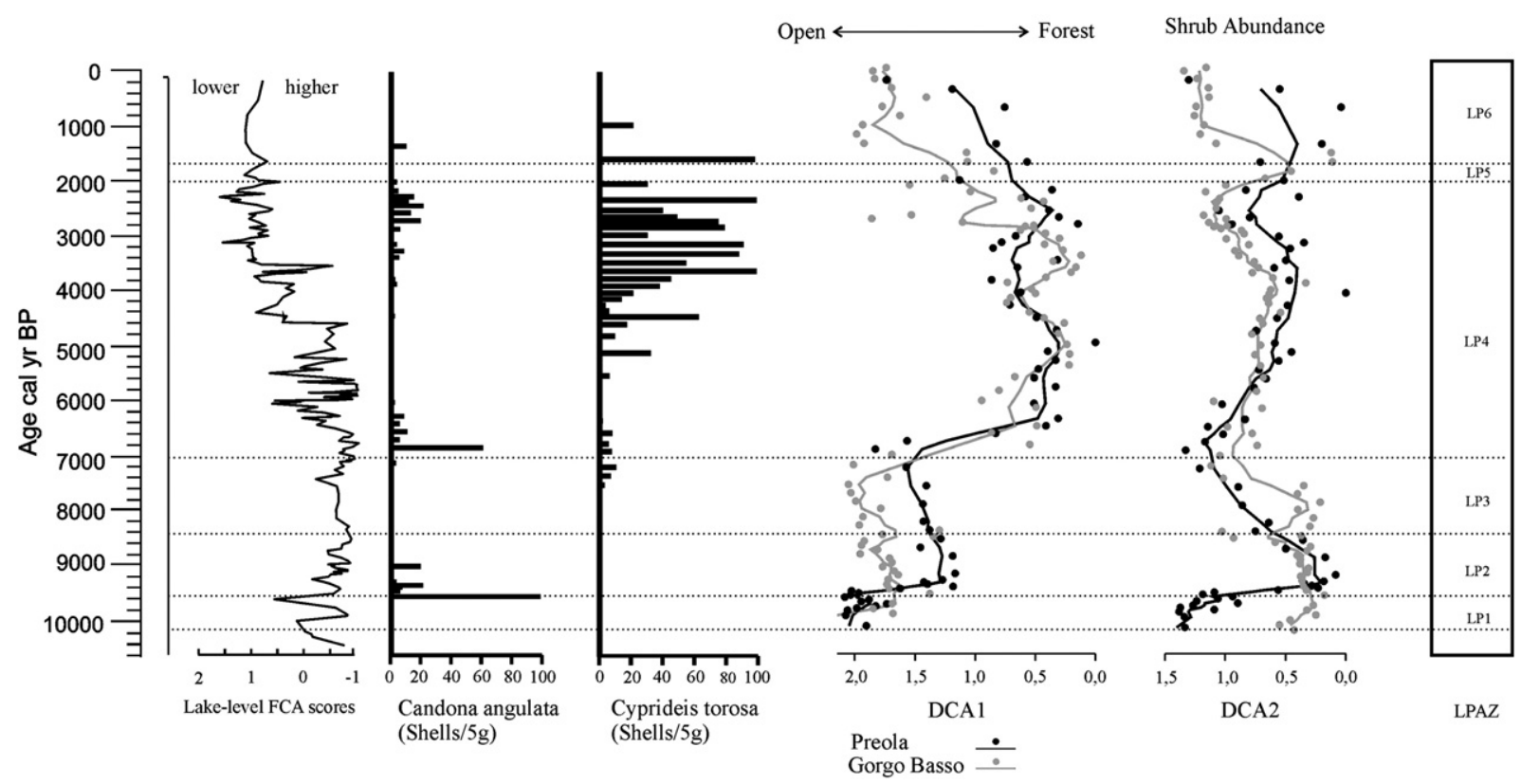

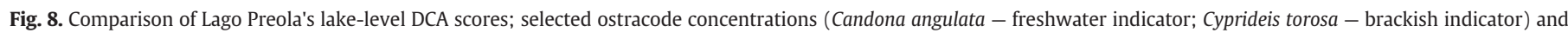
DCA scores from the pollen record (smoothed with 5 point moving average). DCA scores for Gorgo Basso are shown for comparison. 


\subsection{Lake level reconstruction and ostracode assemblages}

The lake level reconstruction for Lago Preola (Fig. 8) shows relative changes, but is non-dimensional, and cannot be directly translated to water depths (Magny et al., 2011). Between the base of the core and $800 \mathrm{~cm}(11,500-10,600 \mathrm{cal}$ yr BP), water levels were low, and the sediment contains little pollen and no ostracodes. Rising lake levels after 10,300 cal yr BP coincide with first detectable pollen (i.e. Zone LP1), and preservation of ostracodes (Fig. 8). Thus it is likely that water was persistent in Lago Preola after this time. However, lake levels were probably highly variable before about $9600 \mathrm{cal} \mathrm{yr} \mathrm{BP}$ (Magny et al., 2011). The level of Lago Preola was generally high between 9600 and 4500 cal yr BP. Candona angulata, a species typical of fresh to slightly brackish waters, is abundant during this interval, which is consistent with high lake levels. Ostracode abundance is very low between 7500 and $6400 \mathrm{cal}$ yr BP, possibly because the high water depth produced anoxic sediments where preservation was poor. Although water levels generally remained high until about $4500 \mathrm{cal}$ yr BP, lake-level variability increased after 6600 cal yr BP. An increase in ostracodes tolerant of brackish conditions after $6600 \mathrm{cal}$ yr BP (e.g. Cyprideis torosa) indicates salinity increased as lake levels became more variable. Lake levels fell after $4500 \mathrm{cal}$ yr BP, and the ostracode assemblage shifts to dominance by brackish indicators. Lake levels remained generally low, and the water saline through the remainder of the Holocene.

\section{Discussion}

\subsection{Separating regional and local vegetation dynamics during the Holocene}

With the exception of pollen source area, the major factors affecting the composition of pollen assemblages do not differ between Lago Preola and nearby Gorgo Basso. Because the lakes are situated only $1 \mathrm{~km}$ apart, they are surrounded by the same regional vegetation and experience the same climatic conditions. Despite this proximity, it is unlikely that the two lakes were connected in the past. Connectivity would require Lago Preola to be at least $6 \mathrm{~m}$ above its current level (Italian Geographic Military Institute). Therefore, we attribute differences between our new Lago Preola pollen profile and the Gorgo Basso record (Tinner et al., 2009) to (1) a higher percentage of pollen from regional sources at Lago Preola, and (2) a higher proportion of pollen from local sources at Gorgo Basso. In contrast, Lago Preola and Biviere di Gela (Noti et al., 2009) $160 \mathrm{~km}$ to the east, have differing climates and separate sources of regional and background pollen. At present, the climate is significantly drier at Biviere di Gela (Fig. 2), and it is likely that a west-to-east gradient in precipitation abundance existed throughout the Holocene.

Comparison of pollen types with distinct dispersal abilities supports our interpretation of the importance of different pollen source areas among Lago Preola, Gorgo Basso, and Biviere di Gela. For example, Pinus spp. produces high amounts of well-dispersed pollen, resulting in a significant component of regional pollen deposition even where pine is not locally abundant (Andersen, 1973; Calcote, 1995). Because of the greater proportion of regional pollen, Pinus percentages are consistently higher at Lago Preola than at Gorgo Basso (Fig. 6). Whereas Pinus reaches $10 \%$ of the pollen sum at Lago Preola during the early Holocene (i.e. about 9500 cal yr BP), it never contributes more than $2 \%$ at Gorgo Basso. Influx of Pinus is highest at both sites during the early Holocene, possibly because of the absence of a forest canopy that could block regional pollen inputs. Pinus is generally more abundant at Biviere di Gela than at Preola (Fig. 6), probably because of a larger catchment area, and therefore more regional pollen inputs. In contrast, the abundance Urtica dioica type is indicative of local pollen influx. Although $U$. dioica is a prolific pollen producer, in Sicily it is restricted to perennially-moist habitats and therefore only locally abundant (Wolters et al., 2005; Ranta et al., 2008). Therefore, the very high Urtica dioica type percentages (i.e. up to $40 \%$ ) at Gorgo Basso before 7000 cal yr BP indicate a very local source, such as the lake shore, as suggested in the original publication (Tinner et al., 2009). Although Urtica dioica type is also common at Lago Preola, where it probably also grew near the shoreline during this period, it never reaches more than $5 \%$ of the pollen sum. This striking difference validates our interpretation of a higher sensitivity of Gorgo Basso than Lago Preola to local pollen inputs.

\subsection{Regional forest development during the Holocene}

Overall similarities in the temporal trends of tree pollen percentage, influx, and DCA axis 1 at Lago Preola and Gorgo Basso support the conclusion that evergreen forests developed in the region surrounding Lago Preola after $7000 \mathrm{cal}$ yr BP, and persisted well into the late Holocene. High influx and percentages of tree pollen at both lakes between 7000 and $2200 \mathrm{cal} \mathrm{yr} \mathrm{BP}$ indicates that forests were not restricted to favorable moist microsites near Gorgo Basso, but instead were widespread in the surrounding region (Figs. 4, 6). Unique local conditions also did not allow forests to persist longer near Gorgo Basso than in the surrounding region. Instead, the collapse of forests and shift to a more open landscape is coincident at Gorgo Basso and Lago Preola (Figs. 6, 8). Thus, evergreen forests remained the dominant vegetation type along the southwestern coast of Sicily until $2600 \mathrm{cal}$ yr BP. However, local and regional differences may have also existed in forest density. Quercus ilex percentages are generally lower at Lago Preola than Gorgo Basso after 5000 cal yr BP, which may mean the regional landscape was more open than the forests near to Gorgo Basso. Likewise, pollen of Pistacia, a shade-intolerant shrub (Pignatti, 2005), is more abundant regionally than locally (Fig. 6).

The available evidence suggests that evergreen forest remained the dominant vegetation type not only in the region surrounding Lago Preola, but also existed at a broader scale along the Sicilian coast, even in drier climatic settings. At Biviere di Gela, high percentages (up to 40\%) of Quercus ilex and Olea europaea indicate that forests also developed to the east of Lago Preola (Noti et al., 2009). However, lower percentages of tree pollen indicate the landscape near Biviere di Gela was more open than the region surrounding Lago Preola, and forests may have been less dense. In addition, forests at Biviere di Gela developed later, and disappeared sooner than at Lago Preola. These differences may mean that forest development was more sensitive to disturbance at Biviere di Gela because of drier climatic conditions.

\subsection{Climatic impacts on vegetation and hydrology}

Increasing moisture availability during the early to mid Holocene probably triggered the two-phase expansion by woody species near Lago Preola. The presence of open grasslands and high fire activity before $9500 \mathrm{cal}$ yr BP coincides with a period of fluctuating lake levels and the absence of ostracodes in the sediment. Thus, precipitation abundance was probably insufficient to support shrublands or provide groundwater inputs adequate to support a lacustrine environment at Lago Preola. Expansion of Pistacia about 9500 cal yr BP coincides with the development of more stable lake levels. Candona angulata, an ostracode species typical of fresh water lakes also first appears and becomes abundant at this time (Fig. 8). This combination of hydrological and vegetational proxies supports our conclusion that increasing moisture allowed Pistacia shrublands to replace the open grasslands by $9500 \mathrm{cal} \mathrm{yr} \mathrm{BP.} \mathrm{Increasing} \mathrm{moisture} \mathrm{also} \mathrm{affected} \mathrm{vege-}$ tation elsewhere in Sicily. Forests developed near Lago Pergusa (667 $\mathrm{m}$ a.s.l) in central Sicily, where the climate is moister and cooler than at Lago Preola (Fig. 2; Sadori and Narcisi, 2001; Zanchetta et al., 2007). However, moisture availability remained insufficient for forest 
development near the coast until 7000 cal yr BP. Development of evergreen forests in the region surrounding Lago Preola occurred when lake level was highest (Fig. 8). C. angulata, the freshwater indicator was also abundant as Quercus ilex and Olea europaea expanded, indicating ample inputs of freshwater supported the lake so that evaporation did not cause a concentration of solutes.

Interesting differences between hydrological change and vegetation dynamics occur at Lago Preola after 7000 cal yr BP. Between 7000 and 4500 cal yr BP, lake levels probably remained high on average, but variability increased (Fig. 8). The high abundance of Quercus ilex, and low abundance of herbaceous types indicates forests were dense during this interval. Cyprideis torosa, an ostracode species typical of saline waters, first appears at this time. The increase in salinity possibly resulted from evaporative concentration of lake water as groundwater inputs declined and the lake level fell. It is also possible that sea water intrusion affected the salinity of Lago Preola. Sea level rose approximately $50 \mathrm{~m}$ after 10,500 cal yr BP around western Sicily, with the largest increase before about 7000 cal yr BP (Antonioli et al., 2002; Lambeck et al., 2004). However, recent studies in the salinity and level of Lago Preola, and groundwater salinity on the south Sicilian coast, relate more to groundwater extraction for agriculture and to the abundance of groundwater recharge, than to the mixing of seawater and groundwater (Cusimano et al., 2006; Manno et al., 2007). The transition to lower lake levels and higher salinity after 4500 cal yr BP does not coincide with the regional collapse of forests. Quercus ilex does decline about 4500 cal yr BP, but this decline is temporary, and forests remained in the region until about $2600 \mathrm{cal} \mathrm{yr} \mathrm{BP}$ (Fig. 8).

The factors that control lake levels are not necessarily the same as those controlling forest vegetation in coastal Sicily. Lago Preola has no surface inlet, and depends on groundwater to maintain a positive hydrological balance. Therefore, changes in lake levels are determined by the amount of water evaporating from the lake surface, and the abundance of groundwater (Cusimano et al., 2006; Giraudi et al., 2011). Groundwater recharge in Mediterranean climates occurs almost exclusively during fall and winter, the only seasons when rainfall exceeds evapotranspiration (Ducci and Tranfaglia, 2008; Fiorillo and Guadagno, 2010). Therefore, the decline in lake levels must have resulted from a decrease in cool season precipitation (Manno et al., 2007; Barone et al., 2010). This interpretation is consistent with the lake-sediment oxygen isotope record from Lago Pergusa (Zanchetta et al., 2007; Roberts et al., 2008). Sedimentary $\delta^{18} \mathrm{O}$ declined at Lago Pergusa during the early Holocene, probably due to increasing inputs of isotopicallydepleted (i.e. winter) precipitation. A shift to higher $\delta^{18} \mathrm{O}$ values after $7000 \mathrm{cal}$ yr BP probably means the abundance of winter precipitation declined so that evaporation and warm-season precipitation became more important to the hydrology of the lake (Leng and Marshall, 2004; Jones and Imbers, 2010).

In contrast to lake levels, Mediterranean forests are more sensitive to the length of the summer dry season than to the abundance of winter precipitation. Although evergreen trees also grow during the moist, mild, Mediterranean winter, most growth occurs during the spring and autumn, when moisture availability is not limiting, and temperatures are favorable (Gratani, 1996; Gulias et al., 2009; Vaz et al., 2010). Precipitation is particularly important during spring when evaporative demand is increasing, and leaf development and shoot elongation are most active (Allard et al., 2008; Misson et al., 2011). Therefore, we hypothesize that forests developed near Lago Preola about 7000 cal yr BP due to an increase in spring precipitation and/or a shortening of the summer-dry period. Increasing warm-season moisture availability at this time coincides with weakening of insolation-driven Hadley circulation, which blocks the eastward flow of moist air to the Mediterranean region during summer (Tzedakis, 2007; Tinner et al., 2009; Tzedakis et al., 2009).

\subsection{Human impacts on vegetation dynamics}

Humans may have contributed to the Pistacia decline and opening of the landscape centered around $7500 \mathrm{cal} \mathrm{yr}$ BP. Ficus pollen co-occurs with other anthropogenic indicators at Lago Preola and Gorgo Basso, suggesting early Neolithic agricultural activities (Tinner et al., 2009). The fig tree is native to western Asia, and it was introduced in the Mediterranean basin during Neolithic times (Zohary and Spiegel-Roy, 1975; Zohary and Hopf, 2000). Archeobotanical remains of fig fruits are found in association with einkorn, wheat, lentil and barley in Uzzo cave in northwest Sicily during the early Neolithic (5700 cal AD/BC), which indicates contemporaneous fig cultivation in Sicily (Leighton, 1999).

Neolithic settlements were spread along the coast and evidence of structures, tombs and archeobotanical remains of wheat, domestic lentil, and fig have been found near Lago Preola (Fig. 1; Leighton, 1999). The most important Neolithic settlement in western Sicily, Stretto Partanna, is located $40 \mathrm{~km}$ north of Lago Preola. Its development is placed around $7700 \mathrm{cal}$ yr BP (Tusa, 1999). This site belongs to an advanced stage of Neolithic society in Sicily, as demonstrated by irrigation ditches surrounding the site. Many other minor sites (e.g., Kronio cave, Castello della Pietra, Castelluccio) near Lago Preola provide abundant evidence of Neolithic settlements in southwestern Sicily (Leighton, 1999).

Human impacts probably persisted during the forested period after 7000 cal yr BP but intensified from 2600 to 2200 cal yr BP, causing widespread forest decline along the Sicilian coast. As human disturbance increased, Pistacia shrublands first replaced forests, but intense land use probably caused Pistacia to decline as well after 1500 cal yr BP. Pistacia is more abundant at Lago Preola than Gorgo Basso as the forest declined, and persisted longer at high abundance (Figs. 6, 7). Forest decline and land-use intensification near Lago Preola from 2600 to 2000 cal yr BP probably relate to the Graeco-Roman colonization of coastal Sicily (Fig. 1). Archeobotanical studies indicate cereal production was one of the most important economic activities in coastal Sicily, and that coastal agriculture was of sufficient intensity to support hundreds of thousands of people (De Angelis, 2000). Furthermore, cereal production was not only for local consumption. Sicily was also an important granary for the Mediterranean basin, especially North Africa and Greece (De Angelis, 2002). Greek settlers also directly modified regional hydrology. Written sources record the construction of aqueducts to irrigate crops and to provide water to the cities. For example, impressive aqueducts were built in Morgantina in the sixth century BC (2600 cal yr BP), near Gela, in Syracuse, and in Catania. The technique was widespread all over Sicily (Crouch, 1984), and probably influenced the hydrology of Sicily making anthropogenic lowering of groundwater and lake levels likely. Greek colonization had major consequences for the vegetation of coastal Sicily. Whereas forests persisted under human disturbance near Lago Preola for ca. 5000 years before the Greek colonization of coastal Sicily, it appears that the combination of land-use intensification, new technology, and higher human populations that occurred during the Greek period nearly eliminated forests.

\section{Conclusion}

We propose that, whereas coastal Mediterranean forests are limited by the abundance of spring precipitation and the duration of summer drought, water levels in groundwater-fed lakes such as Lago Preola are most sensitive to the abundance of winter precipitation. Therefore, efforts to link lake-level change and vegetational dynamics in the Mediterranean region should proceed cautiously, and present mechanisms that can link the two. Increasing abundance of pollen indicators of human disturbance at Lago Preola after 2600 cal yr BP suggest that the collapse of forests along the Sicilian coast was mainly caused by increasing human disturbance, not a shift to drier 
conditions during the late Holocene. Instead, the regional occurrence of forests near Lago Preola demonstrates that climatic conditions were favorable for forests in even the driest part of Italy during the middle-late Holocene, and likely remain suitable for forests at present. However, the absence of forests during the early Holocene, when the regional climate was drier near our site indicates that greenhouse forcing could eliminate the potential for forests to reexpand.

\section{Acknowledgments}

We are grateful to Stefania d'Angelo from the Nature Reserve "Lago Preola e Gorghi Tondi" and Willi Tanner for logistical and practical help during the field work. We thank Jacqueline van Leeuwen for support during the analyses. The Swiss National Science Foundation (grant PP00P2-114886) funded this research.

\section{References}

Allen, H., 2003. Response of past and present Mediterranean ecosystems to environmental change. Progress in Physical Geography 27, 359-377.

Allard, V., Ourcival, J.M., Rambal, S., Joffre, R., Rocheteau, A., 2008. Seasonal and annual variation of carbon exchange in an evergreen Mediterranean forest in southern France. Global Change Biology 14, 714-725.

Andersen, S.T., 1973. The differential pollen productivity of trees and its significance for the interpretation of a pollen diagram from a forested region. In: Birks, H.J.B., West, R.G. (Eds.), Quaternary Plant Ecology. Blackwell Scientific Publications, Oxford, pp. 109-115.

Antonioli, F., Cremona, G., Immordino, F., Puglisi, C., Romagnoli, C., Silenzi, S., Valpreda, E., Verrubbi, V., 2002. New data on the Holocenic sea-level rise in NW Sicily (Central Mediterranean Sea). Global and Planetary Change 34, 121-140.

Barone, R., Castelli, G., Naselli-Flores, L., 2010. Red sky at night cyanobacteria delight: the role of climate in structuring phytoplankton assemblage in a shallow, Mediterranean lake (Biviere di Gela, southeastern Sicily). Hydrobiologia 639, 43-53.

Bennett, K.D., 1996. Determination of the number of zones in a biostratigraphical sequence. New Phytologist 132, 155-170.

Beug, H.J., 2004. Leitfaden der Pollenbestimmung für Mitteleuropa und angrenzende Gebiete. Verlag, Munich.

Birks, H.J.B., Gordon, A.D., 1985. Numerical Methods in Quaternary Pollen Analysis. Academic Press, London.

Giardina, G., Raimondo, F.M., Spadaro, V., 2007. A catalogue of plants growing in Sicily. Bocconea, Palermo.

Bonaccorso, B., Bordi, I., Cancelliere, A., Rossi, G., Sutera, A., 2003. Spatial variability of drought: an analysis of the SPI in Sicily. Water Resources Management 17, 273-296.

Brullo, S., Ronsisvalle, G.A., 1975. La vegetazione dei Gorghi Tondi e del Lago Preola presso Mazara del Vallo (Sicilia occidentale). Notiziario Fitosociologico 10 , $45-67$.

Calcote, R., 1995. Pollen source area and pollen productivity: evidence from forest hollows. Journal of Ecology 83, 591-602.

Carriòn, J.S., 2002. Patterns and processes of Late Quaternary environmental change in a montane region of southwestern Europe. Quaternary Science Reviews 21 2047-2066.

Colombaroli, D., Marchetto, A., Tinner, W., 2007. Long-term interactions between Mediterranean climate, vegetation and fire regime at Lago di Massaciuccoli (Tuscany, Italy). Journal of Ecology 95, 755-770.

Colombaroli, D., Tinner, W., van Leeuwen, J., Noti, R., Vescovi, E., Vanniére, B., Magny, M., Schmidt, R., Bugmann, H., 2009. Response of broad-leaved evergreen Mediterranean forest vegetation to fire disturbance during the Holocene: insights from the peri-Adriatic region. Journal of Biogeography 36, 314-326.

Conedera, M., Tinner, W., Crameri, S., Torriani, D., Herold, A., 2006. Taxon-related pollen source areas for lake basins in the Southern Alps an empirical approach. Vegetation History and Archaeobotany 15, 263-272.

Crouch, D.P., 1984. The Hellenistic water system of Morgantina (Sicily): contributions to the history of urbanization. American Journal of Archeology 88, 353-365.

Cusimano, G., Hauser, S., Vassallo, M., 2006. Hydrogeochemistry of a Wetland Area of Southwestern Sicily (Italy). Official Publication of the European Water Association (EWA), pp. 1-15.

De Angelis, F., 2000. Estimating the agriculture base of Greek Sicily. Papers of the British School at Rome 68,111-148.

De Angelis, F., 2002. Trade and agriculture at Megara Hyblaia. Oxford Journal of Archaeology 21, 299-310.

Ducci, D., Tranfaglia, G., 2008. Effects of climate change on groundwater resources in Campania (southern Italy). In: Dragoni, W., Sukhija, B.S. (Eds.), Climate Change and Groundwater. Geological Society Special Publication, London, pp. 25-38.

Ellenberg, H., 1996. Vegetation Mitteleuropas mit den Alpen in ökologischer Sicht. E. Ulmer, Stuttgart.

Finsinger, W., Tinner, W., 2005. Minimum count sums for charcoal-concentration estimates in pollen slides: accuracy and potential errors. The Holocene 15, 293-297.
Fiorillo, F., Guadagno, F.M., 2010. Karst spring discharges analysis in relation to drought periods, using the SPI. Water Resources Management 24, 1867-1884.

Giraudi, C., Magny, M., Zanchetta, G., Drysdale, R.N., 2011. The Holocene climatic evolution of Mediterranean Italy: a review of the continental geological data. The Holocene 21, 105-115.

Gratani, L., 1996. Leaf and shoot growth dynamics of Quercus ilex L. Acta OecologicaInternational Journal of Ecology 17, 17-27.

Gulias, J., Cifre, J., Jonasson, S., Medrano, H., Flexas, J., 2009. Seasonal and inter-annual variations of gas exchange in thirteen woody species along a climatic gradient in the Mediterranean island of Mallorca. Flora 204, 169-181.

Hammer, Ø., Harper, D.A.T., Ryan, P.D., 2001. PAST: Paleontological statistics software package for education and data analysis. Palaeontologia Electronica 4, 0-9.

Hofstetter, S., Tinner, W., Valsecchi, V., Carraro, G., Conedera, M., 2006. Lateglacial and Holocene vegetation history in the Insubrian Southern Alps-new indications from a small-scale site. Vegetation History and Archaeobotany 15, 87-98.

Jackson, S.T., 1990. Pollen source area and representation in small lakes of the northeastern United States. Review of Palaeobotany and Palynology 63, 53-76.

Jones, M.D., Imbers, J., 2010. Modeling Mediterranean lake isotope variability. Global and Planetary Change 71, 193-200.

Lambeck, K., Antonioli, F., Purcell, A., Silenzi, S., 2004. Sea-level change along the Italian coast for the past 10,000 yr. Quaternary Science Reviews 23, 1567-1598.

Leighton, R., 1999. Sicily Before History: An Archaeological Survey from the Palaeolithic to the Iron Age. Cornell University Press, Ithaca, New York.

Leng, M.J., Marshall, J.D., 2004. Palaeoclimate interpretation of stable isotope data from lake sediment archives. Quaternary Science Reviews 23, 811-831.

Magny, M., Vannière, B., Calò, C., Millet, L., Peyron, O., Zanchetta, G., La Mantia, T., Tinner, W., 2011. Holocene hydrological changes in south-western Mediterranean as recorded by lake-level fluctuations at Lago Preola, a coastal lake in southern Sicily, Italy. Quaternary Science Review 30, 2459-2475.

Manno, E., Vassallo, M., Varrica, D., Dongarrà, G., Hause, S., 2007. Hydrogeochemistry and Water Balance in the Coastal Wetland Area of "Biviere di Gela," Sicily, Italy. Water, Air, and Soil Pollution 178, 179-193.

Martens, K., 1984. On the freshwater ostracods (Crustacea, Ostracoda) of the Sudan, with special reference to the Red Sea Hills, including a description of a new species. Hydrobiologia 110, 137-161.

Meisch, C., 2000. Freshwater Ostracoda of Western and Central Europe. Spektrum Akademischer Verlag, Heidelberg, Berlin.

Misson, L., Degueldre, D., Collin, C., Rodriguez, R., Rocheteau, A., Ourcival, J.M., Rambal, S., 2011. Phenological responses to extreme droughts in a Mediterranean forest. Global Change Biology 17, 1036-1048.

Moore, P.D., Webb, J.A., Collinson, M.E., 1991. Pollen Analysis, Second Ed. Blackwell Scientific Publications, London.

Noti, R., van Leeuwen, J.F.N., Colombaroli, D., Vescovi, E., Pasta, S., La Mantia, T., Tinner, W., 2009. Mid- and late-Holocene vegetation and fire history at Biviere di Gela, a coastal lake in southern Sicily, Italy. Vegetation History and Archaeobotany 18, 371-387.

Ottonello, D., La Mantia, A., Calvaruso, I., 2003. Indagini preliminari finalizzate allo studio della vegetazione della Riserva Naturale Integrale Lago Preola e Gorghi Tondi (Sicilia sud-occidentale). $98^{\circ}$ Congresso della Società Botanica Italian (Catania, 24-26.09), riassunti:300.

Pellizzaro, G., Cesaraccio, C., Sirca, C., Asunis, C., 2004. Caratteristiche ecofisiologiche e variazione stagionale degli elementi minerali nella specie Chamaerops humilis L. Italus Hortus 11, 107-110.

Pignatti, S., 2005. Valori di bioindicazione delle piante vascolari della flora d'Italia. Braun-Blanquetia 39, 3-97.

Punt, W., 1976. Northwest Europaean Pollen Flora. Elsevier, Amsterdam.

Ranta, H., Sokol, C., Hicks, S., Heino, S., Kubin, E., 2008. How do airborne and deposition pollen samplers reflect the atmospheric dispersal of different pollen types? An example from northern Finland. Grana 47, 285-296.

Reille, M., 1992. Pollen et spores d'Europe et d'Afrique du nord. Laboratoire de Botanique historique et Palynologie, Marseille.

Reimer, P.J., Baillie, M.G.L., Bard, E., Bayliss, A., Beck, J.W., Bertrand, C.J.H., Blackwell, P.G., Buck, C.E., Burr, G.S., Cutler, K.B., Damon, P.E., Edwards, R.L., Fairbanks, R.G., Friedrich, M., Guilderson, T.P., Hogg, A.G., Hughen, K.A., Kromer, B., McCormac, F.G., Manning, S.W., Ramsey, C.B., Reimer, R.W., Remmele, S., Southon, J.R., Stuiver, M., Talamo, S., Taylor, F.W., van der Plicht, J., Weyhenmeyer, C.E., 2004. IntCal04terrestrial radiocarbon age calibration, 26-0 ka BP. Radiocarbon 46, 1029-1058.

Roberts, N., Jones, M.D., Benkaddour, A., Eastwood, W.J., Filippi, M.L., Frogley, M.R., 2008. Stable isotope records of Late Quaternary climate and hydrology from Mediterranean lakes: the ISOMED synthesis. Quaternary Science Reviews 27, 2426-2441.

Roberts, N., Brayshaw, D., Kuzucuoglu, C., Perez, R., Sadori, L., 2011. The mid-Holocene climatic transition in the Mediterranean: causes and consequences. The Holocene $21,3-13$.

Sadori, L., Narcisi, B., 2001. The Postglacial record of environmental history from Lago di Pergusa, Sicily. The Holocene 11, 655-671.

Sanchez-Blanco, M.J., Rodríguez, P., Morales, M.A., Ortuño, M.F., Torrecillas, A., 2002. Comparative growth and water relations of Cistus albidus and Cistus monspeliensis plants during water deficit conditions and recovery. Plant Science 162, 107-113.

Stockmarr, J., 1971. Tablets with spores used in absolute pollen analysis. Pollen et Spores 13, 615-621.

Sugita, S., 1993. A model of pollen source area for an entire lake surface. Quaternary Research 39, 239-244.

Sugita, S., 1994. Pollen representation of vegetation in quaternary sediments: theory and method in patchy vegetation. Journal of Ecology 82, 881-897. 
Stuiver, M., Reimer, P.J., Bard, E., Beck, J.W., Burr, G.S., Hughen, K.A., Kromer, B. McCormac, G., Van der Plicht, J., Spurk, M., 1998. INTCAL98 radiocarbon age calibration, 24,000-0 cal BP. Radiocarbon 40, 1041-1083.

ter Braak, C.J.F., Prentice, I.C., 1988. A theory of gradient analysis. Advances in Ecological Research: Classic Papers 18, 271-313.

Tinner, W., Conedera, M., Ammann, B., Gäggeler, H.W., Gedye, S., Jones, R., Sägesser, B., 1998. Pollen and charcoal in lake sediments compared with historically documented forest fires in southern Switzerland since AD 1920. The Holocene 8, 31-42.

Tinner, W., van Leeuwen, J.F.N., Colombaroli, D., Vescovi, E., van der Knaap, W.O., Henne Paul, D., Pasta, S., D'Angelo, S., La Mantia, T., 2009. Holocene environmental and climatic changes at Gorgo Basso, a coastal lake in southern Sicily, Italy. Quaternary Science Reviews 28, 1498-1510.

Tinner, W., Hu, F.S., 2003. Size parameters, size-class distribution and area-number relationship of microscopic charcoal: relevance for fire reconstruction. The Holocene 13, 499-505.

Tusa, S., 1999. L'insediemanto neolitico di Stretto nel contesto siciliano. In: Tusa, S., Di Salvo, R., Grimaldi, G., Nicoletti, F., Scaletta, C. (Eds.), Partanna nella preistoria, l'insediamento di Stretto, Edizioni d'Arte "Città di Partanna”, Alcamo, pp. 13-32.

Tzedakis, P.C., 2007. Seven ambiguities in the Mediterranean palaeoenvironmental narrative. Quaternary Science Reviews 26, 2042-2066.
Tzedakis, P.C., Palike, H., Roucoux, K.H., de Abreu, L., 2009. Atmospheric methane, southern Europaean vegetation and low-mid latitude links on orbital and millennial timescales. Earth and Planetary Science Letters 277, 307-317.

Vaz, L., Maroco, J., Ribeiro, N., Gazarini, L.C., Pereira, J.S., Chaves, M.M., 2010. Leaf-leve responses to light in two co-occurring Quercus (Quercus ilex and Quercus suber): leaf structure, chemical composition and photosynthesis. Agroforestry Systems 82, 173-181.

Vogiatzakis, I.N., Mannion, A.M., Griffiths, G.H., 2006. Mediterranean ecosystem: problems and tools for conservation. Progress in Physical Geography 30, 175-200.

Wolters, S., Bittmann, F., Kummer, V., 2005. The first subfossil records of Urtica kioviensis Rogow. and their consequences for palaeoecological interpretations. Vegetation History and Archaeobotany 14, 518-527.

Zanchetta, G., Borghini, A., Fallick, A.E., Bonadonna, F.P., Leone, G., 2007. Late Quaternary palaeohydrology of Lake Pergusa (Sicily, southern Italy) as inferred by stable isotopes of lacustrine carbonates. Journal of Paleolimnology 38, 227-239.

Zohary, D., Spiegel-Roy, P., 1975. Beginnings of fruit growing in the Old World. Science 187, 319-327.

Zohary, D., Hopf, M., 2000. Domestication of Plants in the Old World, 3rd Ed. . Oxford. 